\title{
Blood Vessel Neoplasm
}

National Cancer Institute

\section{Source}

National Cancer Institute. Blood Vessel Neoplasm. NCI Thesaurus. Code C7387.

A neoplasm arising from arteries or veins. 